\title{
Tubular chitosan device for use as prosthesis coating in vascular surgery
}

\author{
Dispositivo tubular de quitosana para uso como revestimento de prótese em cirurgia vascular \\ Dispositivo tubular de quitosano para uso como revestimento de próteses em cirugía vascular
}

Received: 03/18/2021 | Reviewed: 03/24/2021 | Accept: 03/30/2021 | Published: 04/10/2021

\author{
Maria Dennise Medeiros Macêdo \\ ORCID: https://orcid.org/0000-0003-2990-5447 \\ Campina Grande Federal University, Brazil \\ E-mail: dennisemed1 @gmail.com \\ Breno de Medeiros Lucena \\ ORCID: https://orcid.org/0000-0002-0673-4000 \\ Campina Grande Federal University, Brazil \\ E-mail: brenolucena.bl@gmail.com \\ Glauber Rodrigues Cerqueira de Cerqueira \\ ORCID: https://orcid.org/0000-0002-7578-4669 \\ Campina Grande Federal University, Brazil \\ E-mail: glauberrccerqueira@gmail.com \\ Wladymyr Jefferson Bacalhau de Sousa \\ ORCID: https://orcid.org/0000-0002-3931-8265 \\ Campina Grande Federal University, Brazil \\ E-mail: wladymyrjb@yahoo.com.br \\ Thiago Cajú Pedrosa \\ ORCID: https://orcid.org/0000-0002-8801-8322 \\ Campina Grande Federal University, Brazil \\ E-mail: thiago.cajupedrosa@gmail.com \\ Rossemberg Cardoso Barbosa \\ ORCID: https://orcid.org/0000-0002-8551-5251 \\ Campina Grande Federal University, Brazil \\ E-mail: rcbvet@gmail.com \\ Ana Caroline Santana de Azevedo \\ ORCID: https://orcid.org/0000-0002-6732-8372 \\ Campina Grande Federal University, Brazil \\ E-mail: ana.santana@ certbio.ufcg.edu.br \\ Matheus Ferreira de Souza \\ ORCID: https://orcid.org/0000-0002-2191-2573 \\ Campina Grande Federal University, Brazil \\ E-mail: fdsmatheus@gmail.com \\ Dayanna Kelly Marques de Oliveira \\ ORCID: https://orcid.org/0000-0002-7751-3002 \\ Campina Grande Federal University, Brazil \\ E-mail: oliveiradayanna28@gmail.com \\ Marcus Vinícius Lia Fook \\ ORCID: https://orcid.org/0000-0002-8566-920X \\ Campina Grande Federal University, Brazil \\ E-mail: marcus.liafook@certbio.ufcg.edu.br
}

\begin{abstract}
Chitosan is a natural, biodegradable, non-toxic and biocompatible polymer, with characteristics such as a healing, hemostatic, antimicrobial agent, among others. Therefore, the aim of this study is to develop a tubular chitosan device for use as a prosthetic coating application in vascular surgery. The chitosan wires were obtained by the spinning method in a $2 \mathrm{M}$ sodium hydroxide coagulant solution $(\mathrm{NaOH})$ and used in the form of wires and screens as a reinforcement structure to obtain the tubes. In order to characterize the tubes, optical microscopy, contact angle, degree of swelling, in vitro biodegradation, cytotoxicity and tensile strength were used. The results indicated that the tubes have uniformity over the entire length and as for the resistance to the trace, the tube reinforced with mesh presented greater deformation, while the tube reinforced with wire presented a higher value of rupture stress. The degree of swelling was higher in chitosan tubes with mesh. As for the biodegradation test, it was observed that the lysozyme samples showed greater loss of mass and the cytotoxicity test confirmed the cell viability of the material, concluding that the tubes reinforced with chitosan wires are promising for use in vascular surgeries.
\end{abstract}

Keywords: Chitosan; Tubes; Dip-coating. 


\section{Resumo}

A quitosana é um polímero natural, biodegradável, atóxico e biocompatível, com características como cicatrizante, hemostático, antimicrobiano, entre outras. Portanto, o objetivo deste estudo é desenvolver um dispositivo tubular de quitosana para uso como aplicação de revestimento protético em cirurgia vascular. Os fios de quitosana foram obtidos pelo método de fiação em solução coagulante de hidróxido de sódio $2 \mathrm{M}(\mathrm{NaOH})$ e utilizados na forma de fios e telas como estrutura de reforço para a obtenção dos tubos. Para a caracterização dos tubos, foram utilizados microscopia ótica, ângulo de contato, grau de intumescimento, biodegradação in vitro, citotoxicidade e resistência à tração. Os resultados indicaram que os tubos apresentam uniformidade em todo o comprimento e quanto à resistência ao traço, o tubo reforçado com tela apresentou maior deformação, enquanto o tubo reforçado com arame apresentou maior valor de tensão de ruptura. O grau de inchaço foi maior em tubos de quitosana com tela. Quanto ao teste de biodegradação, observou-se que as amostras de lisozima apresentaram maior perda de massa e o teste de citotoxicidade confirmou a viabilidade celular do material, concluindo que os tubos reforçados com fios de quitosana são promissores para uso em cirurgias vasculares.

Palavras-chave: Quitosana; Tubos; Revestimento por imersão.

\section{Resumen}

El quitosano es un polímero natural, biodegradable, atóxico y biocompatible, con características como cicatrizante, hemostático, antimicrobiano, entre otras. Por lo tanto, el objetivo de este estudio es desarrollar un dispositivo tubular de quitosano para su uso como aplicación de recubrimiento protésico en cirugía vascular. Los alambres de quitosano se obtuvieron por el método de hilado en una solución coagulante de hidróxido de sodio $2 \mathrm{M}(\mathrm{NaOH})$ y se utilizaron en forma de alambres y pantallas como estructura de refuerzo para la obtención de los tubos. Para caracterizar los tubos se utilizó microscopía óptica, ángulo de contacto, grado de hinchamiento, biodegradación in vitro, citotoxicidad y resistencia a la tracción. Los resultados indicaron que los tubos tienen uniformidad en toda la longitud y en cuanto a la resistencia a la línea, el tubo reforzado con malla presentó mayor deformación, mientras que el tubo reforzado con alambre presentó un mayor valor de esfuerzo de rotura. El grado de hinchamiento fue mayor en los tubos de quitosano con malla. En cuanto a la prueba de biodegradación, se observó que las muestras de lisozima presentaron mayor pérdida de masa y la prueba de citotoxicidad confirmó la viabilidad celular del material, concluyendo que los tubos reforzados con alambres de quitosano son prometedores para su uso en cirugías vasculares.

Palabras clave: Quitosano; Tubos; Recubrimiento por immersión.

\section{Introduction}

Biomaterials can be understood as substances, natural or synthetic, designed and shaped in such a way that they can be used for a period of time in the organism, so that alone or as part of a system, it directs and controls interactions with living components, in diagnostic or therapeutic procedures, in human or veterinary medicine (Keane \& Badylak, 2014; Park \& Lakes, 2007; Williams, 2008).

Polymeric biomaterials, mainly based on chitosan, constitute a class of materials with several applications related to tissue engineering. They have been used in several fields in the medical sciences, from controlled drug release to tissue engineering (Gomes et al., 2008).

Chitosan is a linear biopolymer generally obtained by alkaline desacetylation of chitin, which is a polysaccharide consisting of 2-acetamide-2-deoxy-D-glucopyranose units linked via $\beta(1 \rightarrow 4)$ linkage. It has great economic and environmental importance as it is obtained from chitin, which is the second natural polymer present in nature (Chen, Kuo, \& Lee, 2012). It is studied as an important constituent of biomaterials useful for the treatment of wounds, since it can accelerate the healing of injuries, in the prevention of infections, in the development of membranes for hemodialysis, and other functions, such as in development of films with action antimicrobial for preserving meats, fruits and cereals (Ávila, Bierbrauer, Pucci, LópezGonzález, \& Strumia, 2012; Chen et al., 2012; Peter, 2005).

Within the scope of medical activities, it is possible to highlight several interventions related to the need for repair vascular surgery, airway management, and treatment of esophageal stenosis or hemorrhagic diseases. Thus, there is a need for the availability of specific tubular devices that are implanted, sometimes in the light of the affected organ to maintain its shape, sometimes in replacement of these organs (Hendow et al., 2016).

Cárdenas-Triviño and Soto-Seguel (2020) manufactured tubes of chitosan (CS), polylactic acid (PLA) and calcium 
glumate (Glu.Ca) for use in nerve repair and the compound with CS 4\% + Glu.Ca 1\% + PLA 2\% was the best option due to its lower solubility, making colapse impossible when nerve application. Crosio et al. (2019) used chitosan tubes with a structure of skeletal muscle fibers to repair the median nerve of rats as a way to provide a three-dimensional environment and trophic factors that support the regrowth of the axon in nerves. Silva, Rodrigues, Silva, Reis, and Duarte (2018) created tubular structures based on crosslinked chitosan with genipin, showing that crosslinking favors cell adhesion and mechanical property, opening up the possibility of potential use in bone tissue engineering.

The studies with chitosan tubes reported in the literature are being conducted mostly in the use for the regeneration of injured nerves and other types of injury, therefore, there is a need for new applications in tubular organs. Therefore, the objective of this work is the development of a tubular chitosan device, reinforced with the wires and screens for use like prosthesis coating in vascular surgery.

\section{Methodology}

The following materials and reagentes were used for the development of this work: Medium molecular weight chitosan with molecular weight of $260 \mathrm{KDa}$ and a deacetylation degree of approximately 90\%, produced in the CERTBIO-UFCG (Campina Grande, PB, Brazil). Phosphate buffered saline (PBS) and lysozyme - Sigma Aldrich. Glacial acetic acid P.A; Propanotriol glycerin and Sodium hydroxide $(\mathrm{NaOH})-$ Vetec.

The chitosan yarns were prepared using the wet spinning method adapted from previous work of Da Silva, Leal, Da Silva, and Fook (2019). First, the chitosan solution (3\% w/v) was prepared by dissolving the polymer in aqueous solution of glacial acetic acid (1\% v/v) in a volumetric flask, measuring the final volume of $100 \mathrm{ml}$. The dissolution of chitosan in the acetic acid solution was carried out undem mechanical stirring $(200 \mathrm{rpm})$ at room temperature $\left(24^{\circ} \mathrm{C}\right)$ for $2 \mathrm{~h}$. The dissolution of chitosan in the acetic acid solution was carried out under mechanical stirring (200 rpm) at room temperature $\left(24{ }^{\circ} \mathrm{C}\right)$ for $2 \mathrm{~h}$. The chitosan solution was placed in syringes (20 mL capacity and $1 \mathrm{~mm}$ diameter tip) and was spun using $\mathrm{g}=\mathrm{flow}$ of $0,7 \mathrm{~mL} / \mathrm{h}$, directly into coagulant bath (aqueous solution of $2 \mathrm{~mol} / \mathrm{L} \mathrm{NaOH}$ ) using an injection pump (Harvard Apparatus, Pump 11 Elite) for $30 \mathrm{~min}$. Then the yarns were removed, washed with distilled water, submitted to drying at an average room temperature $\left(24{ }^{\circ} \mathrm{C}\right.$ ) for $24 \mathrm{~h}$, followed by weaving them on a cylindrical loom. For a loom formation a $3 \mathrm{D}$ technical drawing software (Solidworks) was used, then additive manufacturing was used (3D cloner printer, DH Plus GR.39931 model) with diameter 10 $\mathrm{cm}$, length $15 \mathrm{~cm}, 26$ pins on the top and bottom edge as shown in Figure 1.

For the chitosan tube formation, a chitosan solution $(3 \% \mathrm{w} / \mathrm{v})$ was deposited in a container that allowed the adaptation of the dip-coating process with the aid of a pre-defined size mold in order to favor the standardization of the dimensions of the tubes obtained. After the dip-coating process, the whole was immersed in a coagulant bath (aqueous solution of $2 \mathrm{~mol} / \mathrm{L} \mathrm{NaOH}$ ) for $24 \mathrm{~h}$. Then the tubes were removed and washed with distilled water, where they remained immersed for 90 min. After washing, the tubes were immersed in glycerin for $24 \mathrm{~h}$ and then went through the drying process $\left(24{ }^{\circ} \mathrm{C}\right)$ for $24 \mathrm{~h}$. The screen formed on the loom was wrapped in a cylindrical mold that later went through the dip-coating process. For the formation of the tube spun with chitosan, the wire wrapped in a cylindrical mold as a thread on a spool and subsequently subjected to the dipcoating process to form the tubes. All steps were performed at room temperature $\left(24{ }^{\circ} \mathrm{C}\right)$. Chitosan tubes without reinforcement and those reinforced with chitosan mesh and wire were coded, respectively, by TQ, TQT and TQF. 
Figure 1. Loom model.

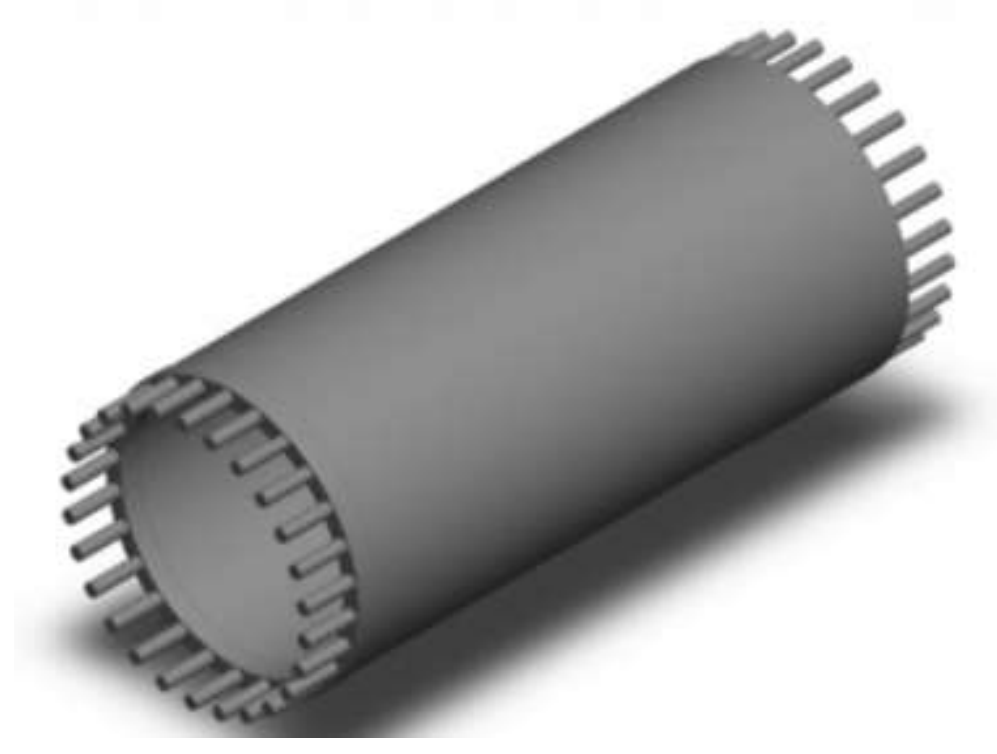

Source: Authors.

Optical microspy test was used to evaluate the morphology and dimensioning of the tubes. The analysis was performed in a Hirox Optical Microscope in reflection and transmission mode, with a range of 50-400x coupled to an image analyses station that has a magnification of up to 3500x. The images were obtained at 6x, 12x and 30x magnification. The stress-strain test aims to indicate the strength, as well as the toughness of the tubes. Experiments were conducted on the mechanical properties testing apparatus (Instron Model 6633), equipped with a load cell of $500 \mathrm{~N}$, speed rate of $50 \mathrm{~mm} / \mathrm{min}$ under ambient conditions, where the temperature was $24{ }^{\circ} \mathrm{C}$ with a relative humidity of 60\%. For this test, the standard ASTM D3039/D 3039 M-17 was used. The samples were used in tube shapes with a length of $3 \mathrm{~cm}$ and a diameter of $5 \mathrm{~mm}$. The tests were performed in quintuplicate for each sample. The contact angle analyses were carried out on the goniometer, after the dripping of distilled water on the surface of the specimens, using a digital camera to capture the image. Later, these images were sent to a computer and analyzed by the angle calculator 1.0 software. These drops were instilled over different areas for each tube sample and five measurements were taken for each drop to obtain the mean.

For swelling test, the tubes were used with a length of $1 \mathrm{~cm}$ and a diameter of $5 \mathrm{~mm}$, dried in an oven for $24 \mathrm{~h}$ at a temperature of $40^{\circ} \mathrm{C}$. After then, they were weighed and placed for 24 hours in petri dishes containing $20 \mathrm{ml}$ of phosphate buffer saline (PBS) at a $1 \mathrm{mg} / \mathrm{L}$ concentration ( $\mathrm{pH}$ close to 7.4). Then, they were placed on a filter paper to remove excess solution and weighed again. The degree of swelling of each sample in time $t$ was calculated using the equation 1 , where $\mathrm{W}_{\mathrm{T}}$ is the weight of the sample at time $t$ and $\mathrm{W}_{\mathrm{O}}$ is the start weight of the sample.

$$
S D(\%)=\frac{W_{T}-W_{O}}{W_{O}} * 100
$$

The biodegradation test was carried out to observe the level of degradation of the tubes during the periods of 7,14 and 21 days, having been carried out based on the ASTM F1635-16 standard. The samples were used with a length of $3 \mathrm{~cm}$ and a diameter of $5 \mathrm{~mm}$. The samples were divided into two groups. The first group was immersed in a $10 \mathrm{ml}$ solution of phosphate buffered saline (PBS) at a concentration of $1 \mathrm{mg} / \mathrm{L}$, as a control ( $\mathrm{pH}$ close to 7.4). The second group, in turn, was immersed in a 
$10 \mathrm{ml}$ PBS solution at a concentration of $1 \mathrm{mg} / \mathrm{L}$, with lysozyme at a concentration of $1.5 \mathrm{mg} / \mathrm{mL}$. The samples were incubated in a microbiological oven at a temperature of $37^{\circ} \mathrm{C}$. After the periods of 7, 14 and 21 days, the samples were removed from the oven, washed with distilled water, and subsequently dried for $24 \mathrm{~h}$ in an oven at a temperature of $40{ }^{\circ} \mathrm{C}$ and then weighed on an analytical balance. The biodegradation was calculated using the equation 2 , where $\mathrm{M}_{\mathrm{i}}$ is the start weight of the sample and $\mathrm{M}_{\mathrm{f}}$ is the final weight of the sample.

$$
M R(\%)=\frac{M_{i}-M_{f}}{M_{i}} * 100
$$

The evaluation of the in vitro cytotoxicity of the tubes was performed by MTT [3-(4,5-dimethylthiazol-2-il)] cell viability assessment test according to ISO 10993-5. The cell line was L929, acquired from the Cell bank of Rio de Janeiro Federal University (Rio de Janeiro, Brazil) and evaluation parameters observed are the percentage of cell death and the IC50 (concentration of the product that inhibits $50 \%$ of cell growth).

The analyses were carried out at the Northeast Biomaterials Evaluation and Development Laboratory - CERTBIO (Campina Grande, Brazil), a laboratory accredited by the ABNT ISO/IEC 17025:2005 Standard, CRL 0799 for Chemical and Biological Tests.

\section{Results and Discussion}

Figure 2 illustrates the optical microscopy images of the TQT samples with a magnification of 6x (1), 12x (2) and 30x (3), where the formation of the nodes and the mesh structure obtained with the chitosan yarns are verified after weaving.

Figure 2. Optical microscopy images of the TQT samples with magnification of $6 x(1), 12 x(2)$ and 30x (3).

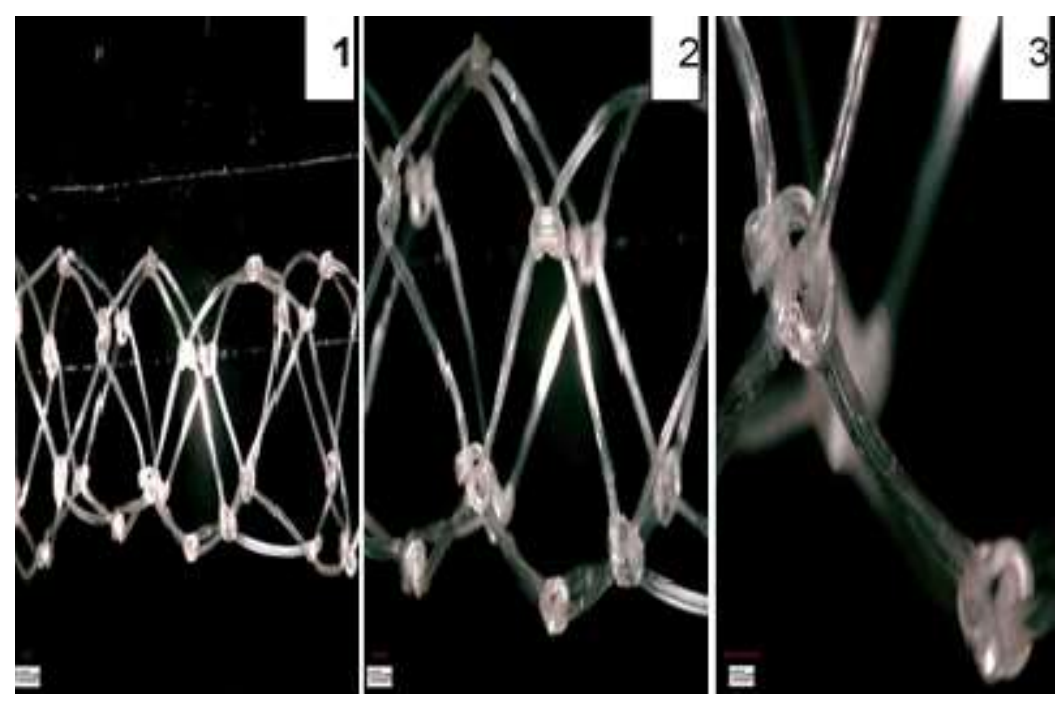

Source: Authors.

The structuring of meshes during the manufacture of tubes allows its application in several areas, especially in medicine. An important example is the surgical meshes used in hernia repair, pelvic organ prolapse, and pelvic floor dysfunction, as well as in endovascular prosthetic devices. Mesh structures generally have higher porosity and the literature reports that these structures have greater tensile strength and greater modulus of elasticity, compared to non-woven structures (Tamayol et al., 2013). 
In the evaluation of the chitosan tubes from the analysis of the OM images (Figure 3), a sense, apparently smooth and pore-free surface was observed, with presence of bubbles from the sample-processing step. The TQF and TQT samples showed morphological differences when compared to the TQ samples due mainly to the presence of a structural chitosan mesh in the first two.

Figure 3. Optical microscopy images of the esternal surfaces of the tubes with magnification of $6 x$ (a) and $12 x$ (b).

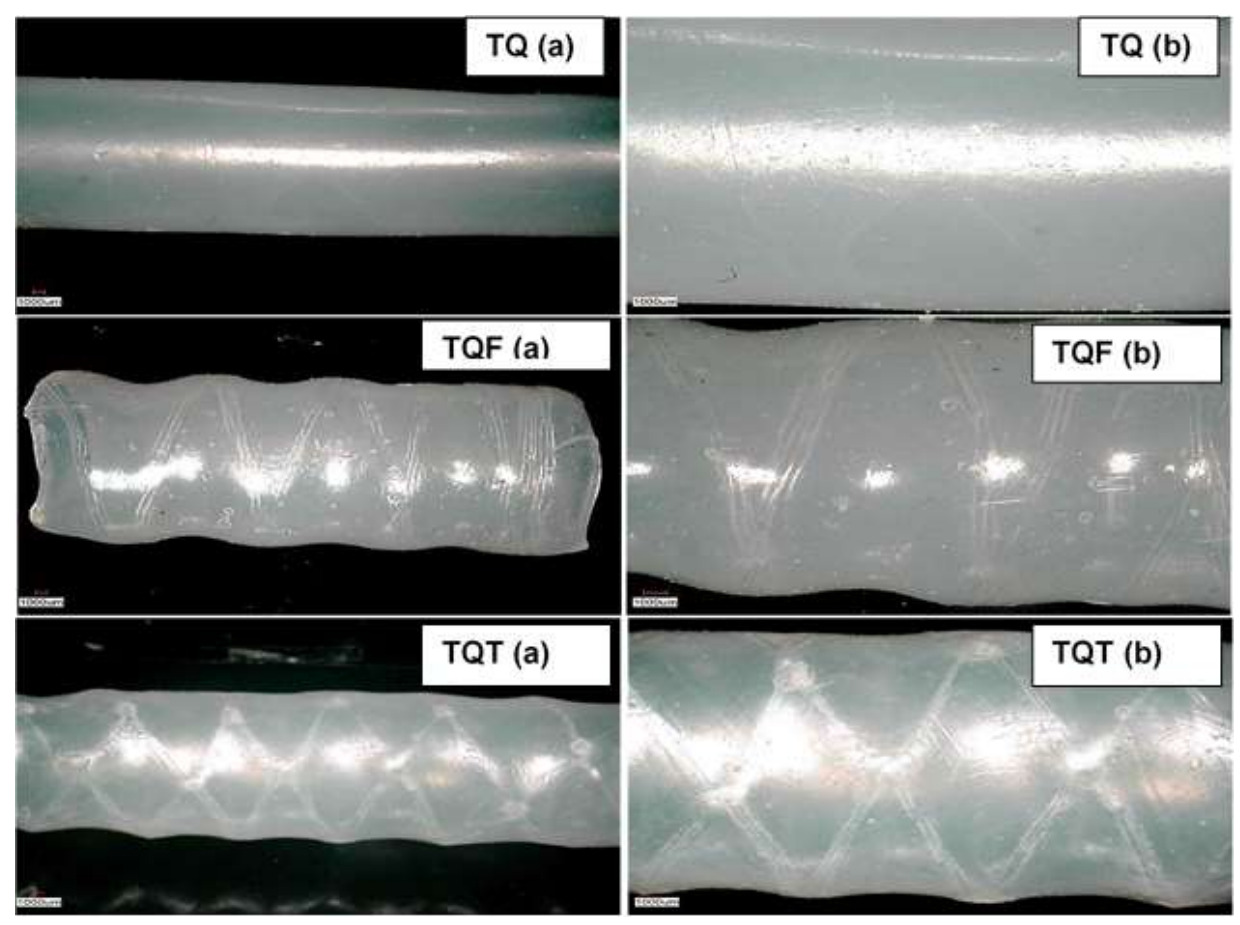

Source: Authors.

Gegel, Shipovskaya, Vdovykh, and Babicheva (2014) produced chitosan tubes and observed that the morphological aspects of the samples depend on the acid uses in dissolution of the polymer. In the samples obtained by lactic acid solution, it was found that the tubes developed has a translucent, smooth and flawless external and internal surface, while, when used with a citric acid solution, the tube obtained opaque, brittle and with an interval layer porous. In Figure 4, the images of the transversal and longitudinal sections of the chitosan tubes are observed, where measurements of the thickness of their walls were made to analyses the uniformity of the samples. It can be seen that the tube wall has an average thickness of $1.4 \mathrm{~mm}$. 
Figure 4. Representative images of optical microscopy of chitosan tubes with magnification of 20x, with the respective measurements of the thickness of the tube wall. Top view of the tube (A) and cross section (B).

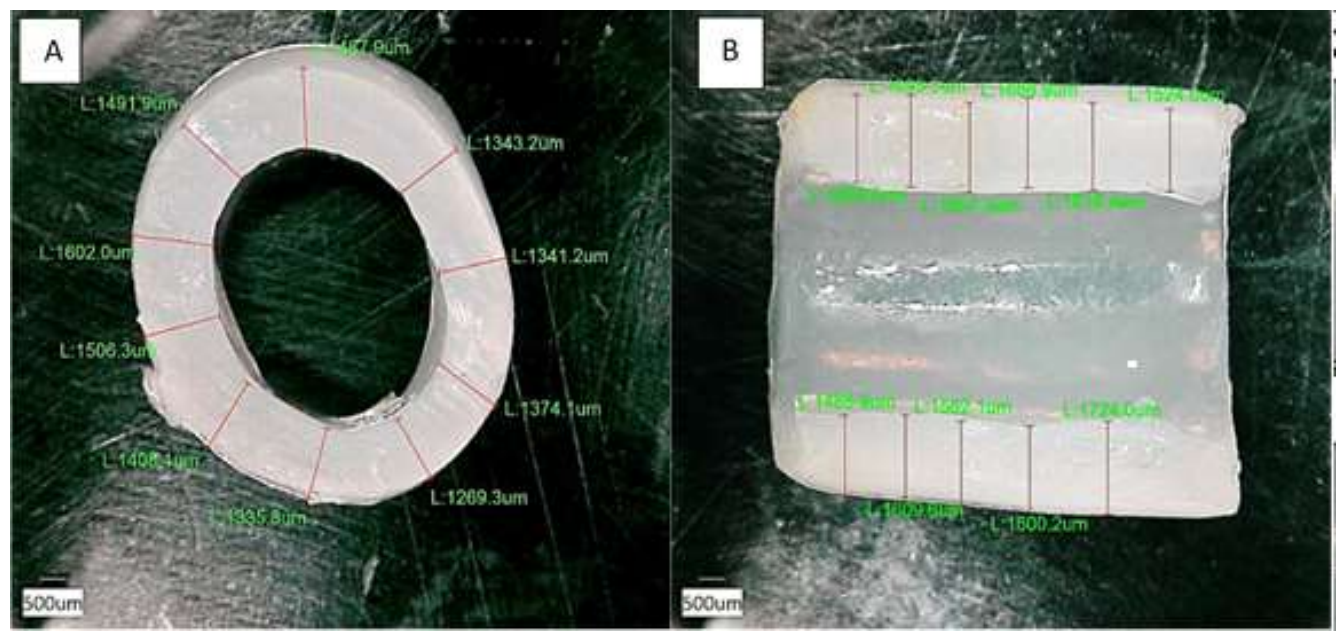

Source: Authors.

The mechanical tensile strength test was carried out to evaluate and compare the strain and stress of the different chitosan tubes. Analyzing the average values of stress and deformation of the tested materials (Table 1), it can be observed that the TQF and TQT samples present greater stress and deformation when compared with TQ samples. The difference is related to the reinforcement with chitosan yarns and screens.

Table 1. Tensile strength in relation to chitosan tubes.

\begin{tabular}{ccc}
\hline Sample & Maximum deformation $(\%)$ & $\begin{array}{c}\text { Maximum breakdown stress } \\
(\mathrm{Mpa})\end{array}$ \\
\hline TQ & $38,49 \pm 4,56$ & $5,80 \pm 0,34$ \\
TQF & $55,56 \pm 7,82$ & $22,42 \pm 0,83$ \\
TQT & $117,19 \pm 6,23$ & $14,20 \pm 0,54$ \\
\hline
\end{tabular}

Source: Authors.

According to Gegel et al. (2014), the mechanical resistance of the chitosan tubes and variations in the stress/strain values are linked to the concentration of the solution in the tube's formation to the morphological and structural aspects, in addition to the sample processing conditions.

Figure 5 shows the measurement of the contact angle for the tubes, it was found that all samples has an angle equal to $0^{\circ}$, this being characterized as a material of hydrophilic character. Sousa et al. (2018) when assessing the wettability of the chitosan ring found similar results. 
Figure 5. Contact angle measurements of the tubes.

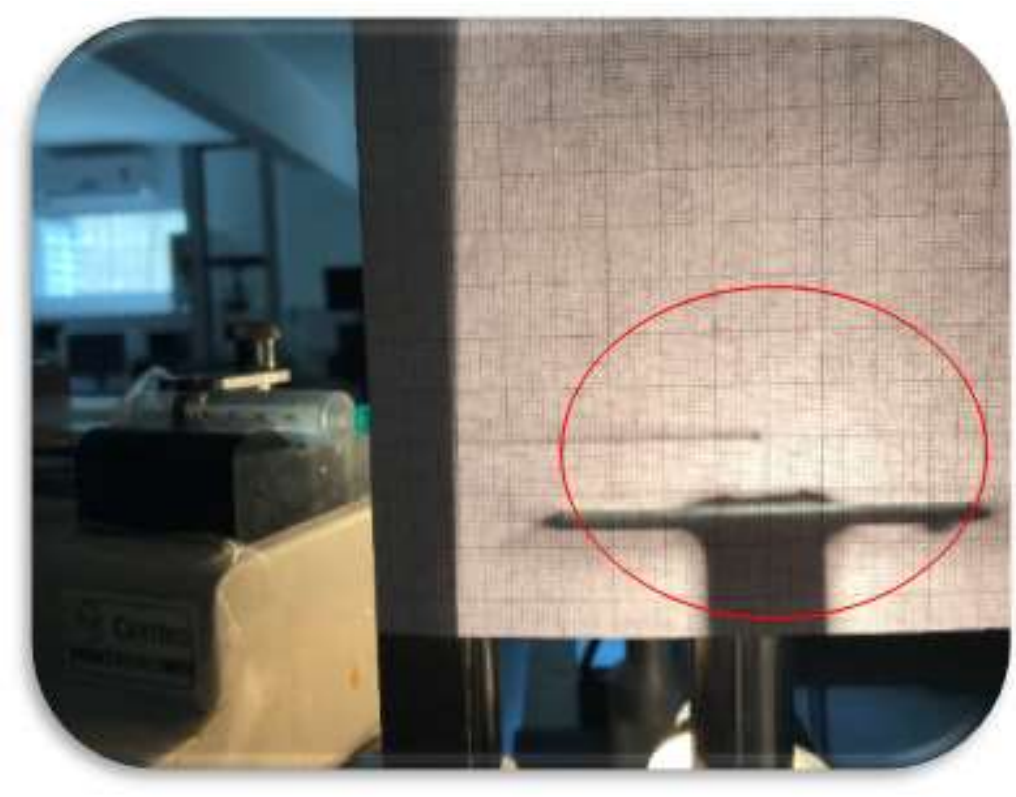

Source: Authors.

The hydrophilicity of the material is of a fundamental importance since the organic medium is predominantly composed of water, thus facilitating its incorporation when implanted in the organism. According to Macêdo, Macêdo, Silva, Silva, and Júnior (2012), wettability is affected by the presence of polar and non-polar groups on the surface. According to Shenvi, Rashid, Ismail, Kassim, and Isloor (2013), concerning chemical reactivity, chitosan has hydrophilic properties due to presence of amino and hydroxyl groups in its structure.

Figure 6 illustrates the degree of swelling of the chitosan tubes, where it can be seen that the woven chitosan tube swelled more than the spun tube and consequently more than the chitosan tube without reinforcement, showing that the reinforcement increases the swelling capacity of the material.

Figure 6. Degree of swelling of chitosan tubes.

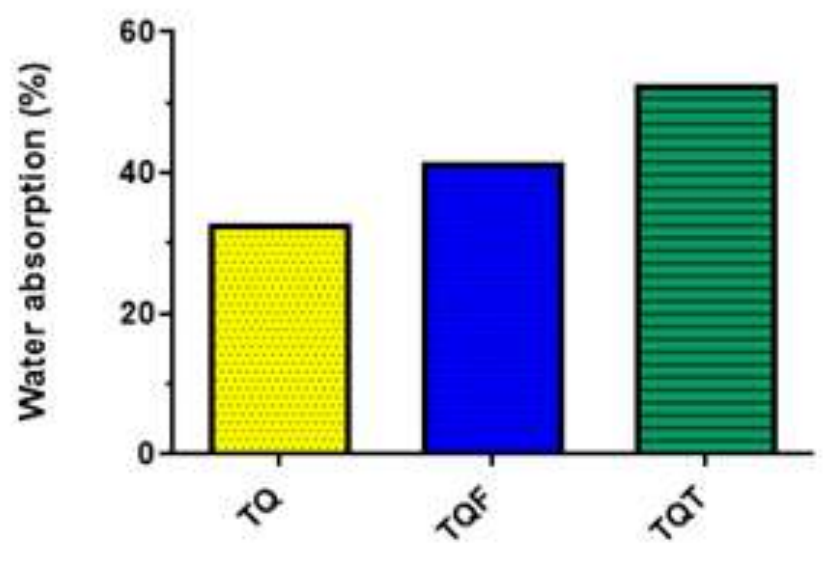

Source: Authors. 
It was observed that the chitosan tubes with glycerin at room temperature, even after prolonged periods, did not present total dehydration of the structure, a finding that is by the intended objective, inferring that the material will not undergo significant changes after contact with a biological fluid. According to Bona (2007), the swelling index is directly related to the solubility in water, being an important parameter for the knowledge of the general characteristics of a material, mainly about its resistance in an aqueous medium, which can be confirmed by him when affirms that solubility is determined by the chemical structure of the material.

Amorphous zones are biodegraded more quickly and consequently reabsorbed than the crystalline regions (Conz, Granjeiro, \& Soares, 2005; Duarte, Júlio, Martins, \& Pezzin, 2004; Shishatskaya, Khlusov, \& Volova, 2006). As the TQT tube has a greater number of wires, thus making the tube less crystalline which directly influences its swelling.

Figures 7 and 8 shows the results of biodegradation of the material in phosphate buffer solution (PBS) without and with lysozyme. The evaluation of the degradation of a biomaterial in the biological environment is extremely important since this characterization is directly related to the time in which the material will be degraded by the organism after its insertion in the human or animal body (De Paoli, 2009).

Figure 7. Biodegradation in PBS solution of chitosan tubes at 7, 14, 21 days interval.

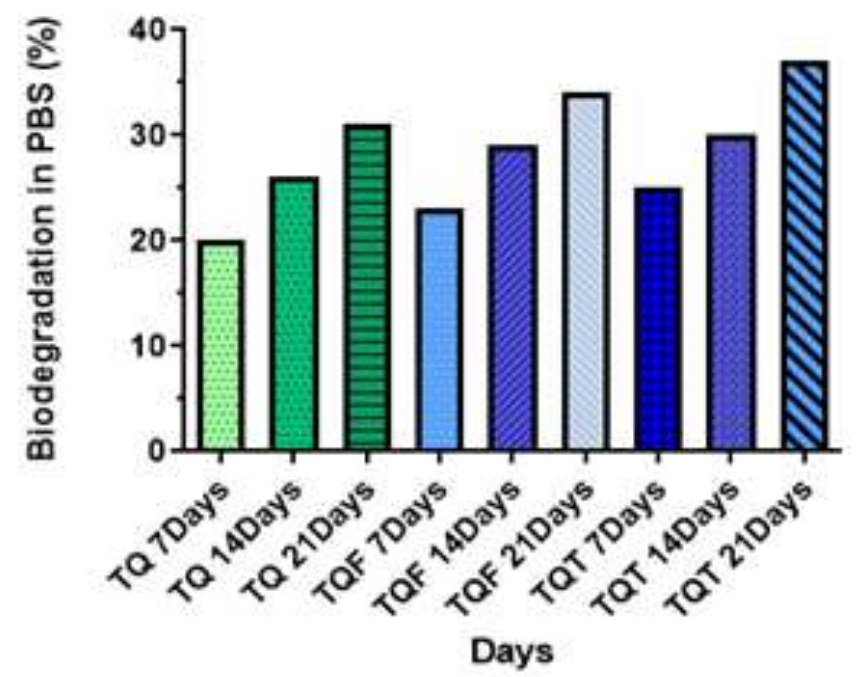

Source: Authors. 
Figure 8. Biodegradation in lysozyme solution of chitosan tubes at 7, 14 and 21 days intervals.

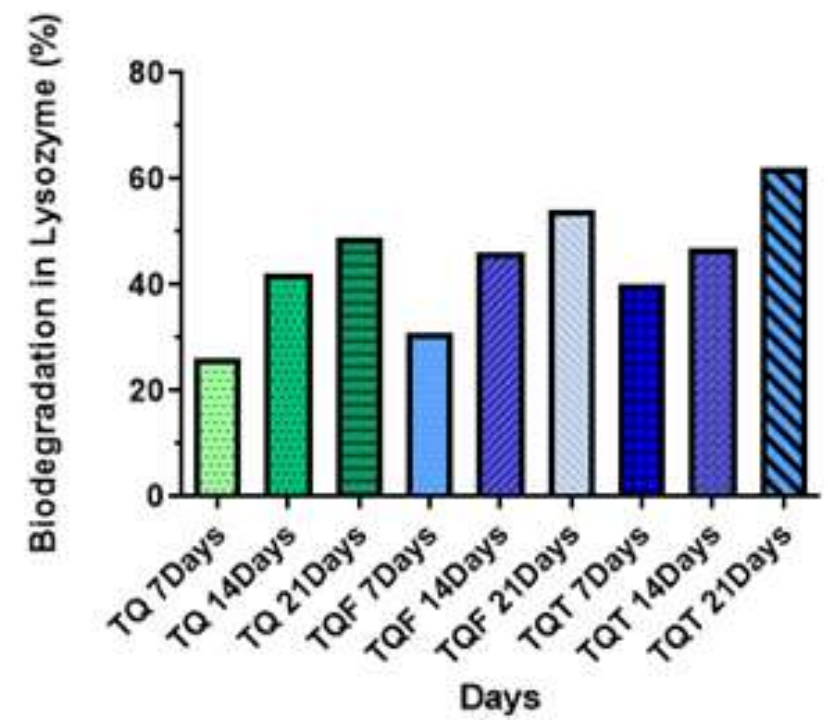

Source: Authors.

Analyzing the values obtained with degradation of the tubes exposed in PBS and lysozyme in the period of 7,14 and 21 days, it was observed that in all samples the degradation was more accentuated under the action of lysozyme, which demonstrates the efficiency of this enzyme in the degradation of chitosan. Peng, Li, Zhang, and Peng (2014) found similar results.

Properties such as molecular weight and degree of deacetylation significantly influence the biodegrability of chitosan, which can be hydrolyzed by enzymes that act by breaking the glycosidic bonds between the glucosamine-glucosamine, glucosamine-N-acetyl-glucosamine and $\mathrm{N}$-acetyl-glucosamine-N-acetyl-glucosamine units. As for the degradation products, that is, oligomers ( $\mathrm{N}$-glucosamine) of chitosan released in the process and its correlation with the physiological responses, it can be said that they have bioactivity and can act as probiotics that act positively, inhibiting the growth of harmful bacteria, increasing immune function and tissue regeneration (Lončarević, Ivanković, \& Rogina, 2017).

Through the biodegradation tests, it is observed that the woven tubes have a greater degradation when compared to the other tubes, which means that their biodegradation is faster and, therefore, their bioabsorption, a characteristic that can be considered positively in the choice of the material that must be implanted for specific purposes.

When analyzing the cytotoxicity percentage (Figure 9) of the tubes, with the minimum value determined by the ISO 10993-5:2009 standard is 70\%, it can be said that these tubes are viable for use in organic environments, since they have a viability percentage above 90\%. Moghadas, Solouk, and Sadeghi (2020) made chitosan membranes and, likewise, found that chitosan is not cytotoxic, indicating that glycerin did not alter cell viability. 
Figure 9. Cell viability of the chitosan tube and spun chitosan tube.

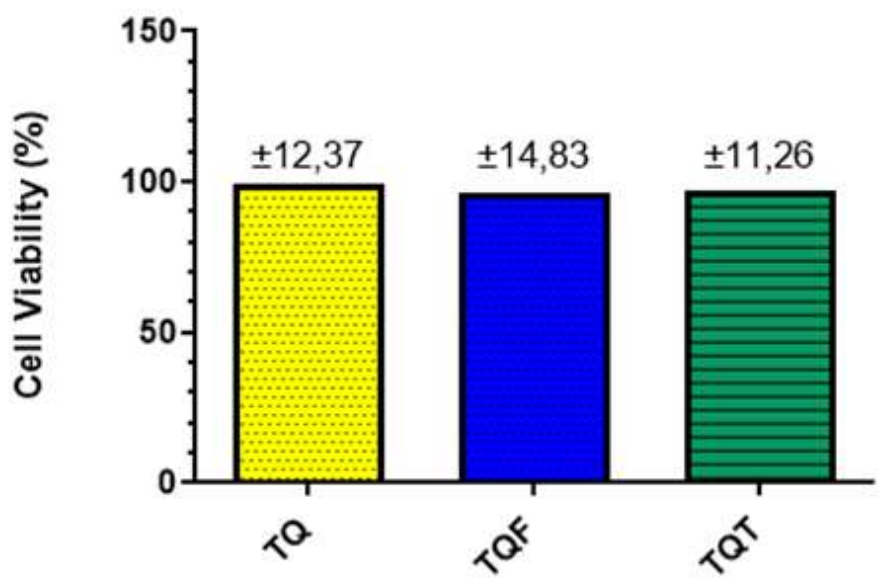

Source: Authors.

\section{Conclusion}

Chitosan tubes reinforced with woven and spun yarns were manufactured for medical intervention purpose. MO results revealed that chitosan tubes are a dense, smooth and pore-free surface compared to chitosan tubes with yarns as a result of the woven's structural presence. The tensile strength tests showed that the woven and spun chitosan tubes have greater tension and deformation when compared to the chitosan tubes. We found that the presence of yarns in the tubes elevates the hydrophilic characteristics of chitosan and the influence of glycerin decreases hydrophilicity. The tubes showed adequate biodegradation and cell viability, thus demonstrating great potential for use as a prosthetic coating in surgical procedures to simplify vascular sutures.

For future work, it is necessary to evaluate the hemostatic effect of chitosan tubes, studying the mechanism by which they favor blood clotting. To develop the tubes as drug carriers for the treatment of infections of vascular prostheses, in addition to conduct pre-clinical assessment of the tubes in vivo, in order to confirm their effectiveness in their use as a vascular wrap.

\section{References}

Ávila, A., Bierbrauer, K., Pucci, G., López-González, M., \& Strumia, M. (2012). Study of optimization of the synthesis and properties of biocomposite films based on grafted chitosan. Journal of Food Engineering, 109(4), 752-761.

Bona, J. C. D. (2007). Preparação e caracterização de filmes biodegradáveis a partir de blendas de amido com polietileno.

Cárdenas-Triviño, G., \& Soto-Seguel, R. (2020). Chitosan composites preparation and characterization of guide tubes for nerve repair. Journal of the Chilean Chemical Society, 65(3), 4870-4878.

Chen, J.-P., Kuo, C.-Y., \& Lee, W.-L. (2012). Thermo-responsive wound dressings by grafting chitosan and poly (N-isopropylacrylamide) to plasma-induced graft polymerization modified non-woven fabrics. Applied Surface Science, 262, 95-101.

Conz, M. B., Granjeiro, J. M., \& Soares, G. d. A. (2005). Physicochemical characterization of six commercial hydroxyapatites for medical-dental applicatons as bone graft. Journal of Applied Oral Science, 13(2), 136-140.

Crosio, A., Fornasari, B. E., Gambarotta, G., Geuna, S., Raimondo, S., Battiston, B., \& Ronchi, G. (2019). Chitosan tubes enriched with fresh skeletal muscle fibers for delayed repair of peripheral nerve defects. Neural regeneration research, 14(6), 1079.

Duarte, M., Júlio, C., Martins, E., \& Pezzin, S. (2004). Estudo da compactação a frio de poli (3-Hidroxibutirato)-Morfologia e resistência à compressão. Revista Matéria, 9(4), 386-391.

Gegel, N. O., Shipovskaya, A. B., Vdovykh, L. S., \& Babicheva, T. S. (2014). Preparation and properties of 3D chitosan microtubes. Journal of Soft Matter, 2014.

Gomes, M., Azevedo, H., Malafaya, P., Silva, S., Oliveira, J., Silva, G., \& Reis, R. (2008). Natural polymers in tissue engineering applications Tissue engineering (pp. 145-192): Elsevier. 
Research, Society and Development, v. 10, n. 4, e25610414031, 2021 (CC BY 4.0) | ISSN 2525-3409 | DOI: http://dx.doi.org/10.33448/rsd-v10i4.14031

Hendow, E. K., Guhmann, P., Wright, B., Sofokleous, P., Parmar, N., \& Day, R. M. (2016). Biomaterials for hollow organ tissue engineering. Fibrogenesis \& tissue repair, 9(1), 1-7.

Keane, T. J., \& Badylak, S. F. (2014). Biomaterials for tissue engineering applications. Paper presented at the Seminars in Pediatric Surgery.

Lončarević, A., Ivanković, M., \& Rogina, A. (2017). Lysozyme-induced degradation of chitosan: the characterisation of degraded chitosan scaffolds. Journal of Tissue Repair and Regeneration, 1(1), 12

Macêdo, M. d. O. C., Macêdo, H., Silva, G., Silva, M., \& Júnior, C. (2012). Estudo comparativo da modificação superficial de membranas de quitosana tratadas por plasma de oxigênio, nitrogênio e hidrogênio. Revista Eletrônica de Materiais e Processos, 7(2), 95-103.

Moghadas, B., Solouk, A., \& Sadeghi, D. (2020). Development of chitosan membrane using non-toxic crosslinkers for potential wound dressing applications. Polymer Bulletin, 1-11.

Paoli, M. A. (2009). Degradação e estabilização de polímeros: Artliber.

Park, J., \& Lakes, R. S. (2007). Biomaterials: an introduction: Springer Science \& Business Media.

Peng, Z., Li, Z., Zhang, F., \& Peng, X. (2014). In-vitro degradation and cytotoxicity of gelatin/chitosan microspheres for drug controlled release. Journal of Macromolecular Science, Part A, 51(8), 646-652.

Peter, M. G. (2005). Chitin and chitosan from animal sources. Polysaccharides and polyamides in the food industry: properties, production, and patents, 115 208.

Shenvi, S. S., Rashid, S. A., Ismail, A., Kassim, M., \& Isloor, A. M. (2013). Preparation and characterization of PPEES/chitosan composite nanofiltration membrane. Desalination, 315, 135-141.

Shishatskaya, E., Khlusov, I., \& Volova, T. (2006). A hybrid PHB-hydroxyapatite composite for biomedical application: production, in vitro and in vivo investigation. Journal of Biomaterials Science, Polymer Edition, 17(5), 481-498.

Silva, J. M., Rodrigues, L. C., Silva, S. S., Reis, R. L., \& Duarte, A. R. C. (2018). Engineered tubular structures based on chitosan for tissue engineering applications. Journal of biomaterials applications, 32(7), 841-852.

Silva, M. C., Leal, R. D. C. A., Da Silva, H. N., \& Fook, M. V. L. (2019). Biodegradable suture threads as controlled drug delivery systems. Materials Research Innovations.

Sousa, W. J. B., Oliveira, L. C. C., Junior, A. G. B., Barbosa, R. C., Fook, M. V. L., Pedrosa, T. C., \& Pimentel, C. A. (2018). Desenvolvimento de anel intravaginal de quitosana/gelatina/promestrieno. Revista Eletrônica de Materiais e Processos, 13(1).

Tamayol, A., Akbari, M., Annabi, N., Paul, A., Khademhosseini, A., \& Juncker, D. (2013). Fiber-based tissue engineering: Progress, challenges, and opportunities. Biotechnology advances, 31(5), 669-687.

Williams, D. F. (2008). On the mechanisms of biocompatibility. Biomaterials, 29(20), 2941-2953. 